\title{
Timsko vodenje in sistematično razvijanje strokovnih timov v vrtcu v luči profesionalnega razvoja
}

\author{
Silvija Komočar
}

\begin{abstract}
Uvod
V prispevku je predstavljena študija primera sistematičnega uvajanja timskega dela na ravni vrtca $v$ Vrtcu Mavrica Brežice kot posledica timskega vodenja vrtca $\mathrm{z}$ namenom spodbujanja profesionalnega razvoja strokovnih delavcev.

Timsko naravnanost in sodelovalno kulturo smo sistematično širili med strokovne delavce in $\mathrm{v}$ zadnjih dveh letih iz delovnih skupin razvili visoko učinkovite strokovne time, ki delujejo na ravni celotnega vrtca. Strokovni delavci se $\mathrm{v}$ okviru svojih timov poglabljajo v različna kurikularna področja predšolske vzgoje in $\mathrm{v}$ skladu s sodobnimi pedagoškimi koncepti posodabljajo svojo prakso ter s tem spodbujajo lasten profesionalni razvoj.

$\mathrm{V}$ prvem razdelku je predstavljen teoretski okvir timskega dela. V njem pokažemo, da znanstvena literatura loči učinkovite time od neučinkovitih in poudarimo bistvene značilnosti uspešnih timov. Izpostavimo pomen komunikacije $\mathrm{v}$ timu ter spodbujanje profesionalnega razvoja v okviru timskega dela. Poudarjamo tudi, da temelji proces spodbujanja in razvijanja timskega dela na vzporednem spodbujanju refleksivnosti članov tima, tako temelji naša študija primera tudi na razvoju odgovornosti članov posameznega strokovnega tima za aktivno lastno vlogo tako pri spodbujanju razvoja tima kot tudi lastnega profesionalnega razvoja.

$\mathrm{V}$ drugem razdelku je predstavljena metodologija raziskave in vzorec za študijo primera. Sledi razdelek Rezultati in razprava, kjer najprej preds-
\end{abstract}


tavimo potek akcijske raziskave v obravnavani organizaciji skozi interpretacije raziskovalcev. Nato so predstavljeni izsledki študije primera, osredotočeni zlasti na primerjave, ki kažejo na dosežene spremembe v okviru pojmovanj in rezultatov sistematičnega razvoja strokovnih timov, ki so jih izpostavili udeleženci raziskave.

Sklepni razdelek predlaga premislek o timskem delu kot orodju za spodbujanje profesionalnega razvoja strokovnih delavcev vrtca v smislu zagotavljanja sodobnega učnega okolja v okviru učeče se skupnosti.

\section{Teoretična opredelitev timskega dela}

V praksi je s pojmom tim velikokrat poimenovana vsaka delovna skupina, sestavljena $\mathrm{z}$ namenom, da opravi neko skupno nalogo. Če pogledamo teoretična izhodišča, pa ugotovimo, da vsaka delovna skupina sama po sebi ni tim, če v njenem delu ne najdemo elementov, ki določajo tim:

- $\quad$ Problemi, ki jih člani tima skupaj rešujejo, so osnova za opredelitev nalog tima, le-te pa so oblikovane za uresničitev cilja.

- Tim dosega cilje $\mathrm{z}$ dobrim medsebojnim sodelovanjem članov tima, čigar velikost je odvisna od kompleksnosti naloge.

- Eden pomembnih elementov timskega dela je prav gotovo usmerjajoči vodja tima, v manjših in utečenih timih, ki so že utečeni pa delo usmerja koordinator. Od njegovih osebnostnih značilnosti in njegove strokovnosti je v marsičem odvisno delovanje tima.

- Zadnji, a zato nikakor najmanj pomembni element timskega dela so po Rozmanu medosebni odnosi med člani in morebitne izmenjave, saj je uspešno timsko delo ključno povezano s kakovostjo medosebnih odnosov (Kobolt, 2012: 6).

Vsako delovno področje zahteva od nas nagle odzive na spremembe, ki se nenehno dogajajo na vseh področjih, pa tudi v nas samih. V sodobnem izobraževalnem okolju pa si v celotni izobraževalni vertikali sprememb želimo, jih načrtno uvajamo. Rutar (2017) govori o dveh vrstah sprememb, ki jih sam sicer opisuje v šolskem okolju, pa vendar jih lahko umestimo tako $\mathrm{v}$ vrtec in v osnovno ali srednjo šolo, kot tudi na fakulteto: prve so notranje spremembe samih učencev in učiteljev, zlasti kakovostne osebnostne, simbolne, duhovne, duševne spremembe učencev, druge pa so zunanje, so spremembe ožjega in širšega družbenega okolja. Nekateri se na spremembe in nova znanja odzivamo hitreje, drugi počasneje, zagotovo pa zahtev- 
ne naloge lažje in bolj kakovostno rešujemo s sodelovanjem. Če izhajamo iz Rutarjeve trditve, da sta ključna dejavnika, ki poganjata dobre spremembe, resnica in vednost oziroma znanje (Rutar, 2017: 128), potem moramo iskati načine, da pedagoškim delavcem zagotovimo učno okolje, kjer bo dovolj prostora za pomembne dobre ideje in produktivne zamisli, ki bodo sprožale najprej nujne spremembe $\mathrm{v}$ njih samih, da bi jih nato lahko razvijali tudi pri svojem delu z otroki. Sodobna nevroznanost poudarja, da naši možgani niso ustvarjeni, da bi v njih zgolj shranjevali podatke, znanje mora biti izbrano, oblikovano in filtrirano skozi mrežo načrtov, ciljev in namer (Rutar, 2017: 128).

Primeren prostor za razvoj dobrih idej in produktivnih zamisli je gotovo tim, vendar ob predpogoju, da lahko $\mathrm{v}$ njem posameznik zadovolji potrebe po varnosti - po predvidljivosti socialnega prostora in zaupanju vanj, kot meni A. Polak (Polak, 2007: 22). Če izhajamo iz trditve Maslowa (Brajša, 1995), da so človeške potrebe hierarhično umeščene $\mathrm{v}$ pet nivojev potreb, pri čemer ugotavlja, da ko nekdo zadovolji en nivo, je motiviran in se trudi, da zadovolji naslednjega, potem lahko sklepamo, da je občutek varnosti ključnega pomena za ustvarjalno mišljenje in produktivno razmišljanje oziroma izpostavljanje posameznika do te mere, da bo svoje ideje tudi delil med ostale člane tima.

Različni avtorji postavljajo podobno pozitivne definicije timskega dela: timsko delo lahko pojmujemo kot večstopenjski proces, v katerem člani tima na individualni in skupinski ravni izpolnjujejo naloge in razvijajo timsko delo (Kozlowski in Klein, 20oo, v Hwang, 2018: 158), pri čemer zajema izpolnjevanje nalog individualno ali skupno opravljanje zadane naloge, običajno podprto $\mathrm{z}$ različnimi pripomočki, medtem ko se timsko delo nanaša na medosebne interakcije med člani tima (Bowers, Braun in Morgan, 1997 v Hwang, 2018). Avtorji se strinjajo, da učinkovito timsko delo opredeljujeta dobra komunikacija in sodelovanje med člani tima na poti do skupnega cilja. Rezultat timskega dela je timska učinkovitost (Salas, Cooke, and Rosen, 2008 v Hwang, 2018), ki je merljiva na različne načine, vključujoč objektivno evalvacijo in refleksijo timske učinkovitosti ter zadovoljstva posameznih članov z delom v timu (Gladstein, 1984; Guchait, Lei, and Tews, 2016; LePine et al., 2008, v Hwang, 2018). Tudi Mayer (2001) vidi v timu (v primerjavi s formalno delovno skupino) povsem novo kakovost in možnost, Brajša (1996) o timu piše kot o živem medosebnem siste$\mathrm{mu}$, njegovo medosebno problematiko pa lahko opazujemo $\mathrm{z}$ več zornih 
kotov: $\mathrm{z}$ vidika medosebne pripadnosti članov tima, njihovega sodelovanja, odnosov, komunikacije, prilagajanja in doživljanja.

Lahko torej povzamemo s sklepom A. Kobolt (2012), da

so timi posebne delovne skupine, ki jih opredeljujejo različne organizacijske oblike, raznolikost $\mathrm{v}$ pogostosti srečevanj, različna dolgost trajanja delovanja, raznovrstnost okoliščin njihovega nastanka in nalog, ki jih opravljajo (Kobolt, 2012: 6).

Učinkoviti timi pa vsebujejo tudi osnovne značilnosti ustvarjalnega tima, ki jih poudarja Mayer (2001: 6): nadseštevnost, vzajemni učinki, velika prožnost, napovedna moč in hitrost učenja ter večja verjetnost nastajanja ustvarjalnih dosežkov.

\section{Učinkovit tim}

Tabela 4r: Pet dimenzij učinkovitega timskega dela po Ohlandu

PRISPEVANJE K TIMSKEMU DELU

- Član prispeva več ali višjo kakovost od pričakovane.

- Članov prispevek pomembno vpliva na izboljšanje dela tima.

- Pomaga dokončati delo kolegov, ki imajo težave.

INTERAKTIVNOST S TIMSKIMI KOLEGI

- Timske kolege spodbuja k podajanju idej in izkazuje interes za njihove ideje in prispevke.

- Izboljšuje komunikacijo med timskimi kolegi. Opogumlja in spodbuja člane tima.

-Timske kolege prosi za povratno informacijo in njihove predloge tudi upošteva pri svojem izboljšanju.

SLEDENJE TIMU

- Opazuje, kako različni dejavniki vplivajo na tim ter opzuje napredek tima.

- Potrudi se, za ustrezen napredek svojih timskih kolegov.

- Svojim timskim kolegom podaja konkretne, redne in konstruktivne povratne informacije.

STREMENJE H KAKOVOSTI

-Tim motivira k odličnosti.

- Pomembno mu je, da tim dosega izjemne rezultate, tudi, kadar za to ni posebnih nagrad.

- Verjame, da lahko tim dosega odlične rezultate.

DOSEGANJE POTREBNEGA ZNANJA, SPRETNOSTI IN VEŠČIN ZA TIMSKO DELO

- Kaže potrebna znanja, spretnosti in veščine za odlično opravljanje dela.

-Pridobiva nova znanja ali spretnosti za izboljšanje učinkovitosti tima.

-Po potrebi prevzame katero koli vlogo v timu.

S. Komočar po: Ohland at al., 20I2, v Hwang, 2018 
Dejavniki, ki vplivajo na učinkovitost tima so predmet številnih raziskav. Različni avtorji poudarjajo, da sestava tima, struktura dela in razdelitev nalog v timu dokazano vplivajo na učinkovitost timskega dela (Gladstein, 1984; Salas, Cooke, and Rosen, 2008, v Hwang, 2018).

A. Polak (2007) po različnih avtorjih konkretneje opredeli lastnosti in delovanje, po katerih se učinkoviti timi razlikujejo od neučinkovitih. Povzamemo lahko, da se učinkovit tim zaveda pozitivne soodvisnosti, pomembnosti odprte in sproščene komunikacije, ki je temelj za boljše medsebojno razumevanje članov tima, poznavanja vlog drugih ter večjega zaupanja med člani, kar zagotovo spodbuja učenje članov tako o drugih kot o sebi. Skupna in jasna vizija povezuje člane tima, vse to pa jim pomaga tako $\mathrm{h}$ kakovostnejšem doseganju načrtovanih skupnih ciljev kot tudi k bolj intenzivnemu profesionalnemu razvoju posameznikov znotraj tima. Tudi sodelovalno vedenje članov tima je za učinkovitost tima izrednega pomena. Da bi lažje razumeli različna vedenja članov v timu, so Loughry, Ohland, and Moore (2007 v Hwang, 2018) razvili lestvico »the Comprehensive Assessment of Team Member Effectiveness « (op. prev.: celovita ocena učinkovitosti članov tima), ki učinkovitost posameznih članov tima razvrsti v 5 kategorij: prispevanje $\mathrm{k}$ timskemu delu, interaktivnost $\mathrm{s}$ timskimi kolegi, sledenje timu, pričakovanje kakovosti ter doseganje potrebnega znanja, spretnosti in veščin za timsko delo.

Tabela v nadaljevanju prikazuje pet dimenzij in opisov vedenj, ki predstavljajo primer učinkovitega timskega dela po Ohlandu (Ohland at al., 2012, v Hwang, 2018).

\section{Komunikacija}

Komunikacija je osnovno orodje timskega dela in je bistvenega pomena, da bi lahko v timu vzdrževali dobre medsebojne odnose in zagotavljali dobre rezultate tima. J. Lepičnik Vodopivec (2012: 15) opredeli komunikacijo kot sestavino človekove eksistence, saj človek nenehno komunicira. Številni raziskovalci timskega dela poudarjajo pomembnost dobre in odprte komunikacije za učinkovito timsko delo, saj vpliva tudi na ostale procese, ki so sestavni del timskega dela (Polak, 2012: 34). Avtorica (prav tam) opozarja, da prav komunikacijski zapleti običajno sprožijo konflikt v timu in vplivajo na timsko neučinkovitost, tako je komunikaciji v timu potrebno posvetiti dodatno pozornost. 
Pri timski komunikaciji se pogosto srečamo s težavami zaradi nepoznavanja štirih pomembnih elementov komunikacije, ki jih izpostavita Robbins in Finley (2000):

1. GOVORJENJE - zelo pomemben del komunikacije, vendar avtorja poudarjata (Ibid.), da še zdaleč ne tako pomemben kot je poslušanje. Pomembno je, da govorimo jasno, razločno, morda počasneje ali pa preprosto glasneje, da smo tako sogovorniku bolj razumljivi.

2. POSLUŠANJE - običajno težji del komunikacije, saj smo osredotočeni bolj na to, kaj želimo sporočiti sogovorniku, torej na lastno govorjenje.

3. POSLUŠANJE GOVORJENJA SAMEGA SEBE - opazovanje načina lastnega govorjenja. Govorec reflektira svoj način sporočanja ob opazovanju svoje verbalne in neverbalne komunikacije.

4. POSLUŠANJE POSLUŠANJA SAMEGA SEBE - razvoj še globljih veščin lastnega poslušanja. Gre za zavedanje zavedanja lastnega poslušanja, za spoštljiv odnos do sogovornika v smislu dejanskega poslušanja njegovega sporočila brez takojšnjega analiziranja, prenagljenega sklepanja, pa tudi sodb. $\mathrm{V}$ tem delu komunikacije gre pravzaprav za odlično avtorefleksijo o tem, kaj nas vznemirja. S poslušanjem lastnega poslušanja preizkušamo potrebe lastnega ega ter lastnih impulzivnih odzivov, raziskujemo torej elemente, ki onemogočajo kakovostno komunikacijo (Robbins in Finley, 2000).

\section{Timsko delo in profesionalni razvoj}

Kompetenten učitelj je zadovoljen s sabo in s svojim delom. Svoje zadovoljstvo prenaša na učence. Njegovo veselje do dela pomembno vpliva na vzdušje v učilnici in se odraža v celotnem izobraževalnem procesu (Grgurić et al., 2009).

Vloga vzgojiteljev in učiteljev se pomembno spreminja, zato jim je zelo pomembno zagotoviti dober sistem profesionalnega razvoja, jim omogočiti razvoj novih kompetenc, večjo avtonomijo in s tem posledično tudi povrniti zaupanje v ta pedagoška poklica. Pedagoški delavci morajo biti kos družbenim spremembam, novim tehnologijam, novim znanjem, novim generacijam. Nenehno se morajo izobraževati, da lahko uspešno opravljajo svojo novo vlogo, ki presega zgolj podajanje znanja. Zato posebej izpostavljamo 
pomen profesionalnega razvoja vzgojiteljev in učiteljev. Če vzamemo za izhodišče trditev, da je

vzgojiteljska profesija izjemno zapletena in zahteva visoko profesionalno zavest in širok razpon kompetenc in da so $\mathrm{z}$ vidika profesionalnega razvoja še posebej pomembne kompetence za raziskovanje prakse in gradnjo nove teorije na podlagi skupnega premišljanja (Šagud in Jurčević Lozančić, 2012, v Valenčič Zuljan in Blanuša Trošelj, 2014: 44),

potem je timska oblika, ki smo jo zastavili v ta namen, ustrezna. Tim je namreč varno okolje, v katerem lahko člani skupno premišljujejo, možgansko viharijo in prihajajo do novih idej, inovativnih pristopov in s tem do novih profesionalnih kompetenc.

Profesionalni razvoj lahko razumemo kot dejavnosti, namenjene podpori in razvoju prakse pedagoških delavcev (Noonan, 2019). In vendar se lahko te dejavnosti med seboj razlikujejo glede na družbeno okolje in oblike izvajanja, kot npr. tečaji na fakultetah, delavnice, formalni in neformalni mentorski odnosi, raziskovalne skupine ali medkolegijale hospitacije (Noonan, 2019).

Raziskovalci različno pristopajo raziskovanju profesionalnega razvoja pedagoških delavcev. Fuller, 1969; Kagan, 1992; Katz, 1972; Berliner,1992 se osredotočijo na faze profesionalnega razvoja in oblikovanje tako imenovanih linearnih faznih modelov. Nekateri raziskovalci se usmerijo na dejavnike, ki vplivajo na profesionalni razvoj, Scheckley in Allen, 1991; Kolb, 1991 pa izpostavljajo oblike in načine poklicnega učenja (v Valenčič Zuljan in Blanuša Trošelj, 2014: 46). P. Javrh (2011) kot eno učiteljevih/vzgojiteljevih temeljnih nalog navaja skrb za nenehno poglabljanje kakovosti vzgojno izobraževalnega dela. Ista avtorica (2011) razlaga, da se kariera razvija učinkovito in harmonično, kadar je uspešno združenih več najpomembnejših prvin: nenehno učenje in iskanje, vseživljenjsko izobraževanje, osebni načrt razvoja kariere, uravnoteženje osebnih ambicij s potrebami družine, razsodno upoštevanje stanja osebnega psihosocialnega razvoja, tekoče soočanje in usklajevanje s potrebami delodajalca ter pravočasno prilagajanje trgu dela.

\section{Metodologija in vzorec}

Kombinirana (kvantitativno-kvalitativna) raziskava, ki je potekala po metodi akcijskega raziskovanja $\mathrm{z}$ udeležbo kot študija primera, je zajemala 
neslučajno priložnosten raziskovalni vzorec, saj smo v raziskavo vključili vnaprej določen vrtec. Vzorec je zajemal 1 vrtec v mestnem okolju, ki ima 27 oddelkov, 88 zaposlenih in 429 otrok.

Izdelali smo akcijski načrt za sistematično razvijanje timskega dela, kjer smo časovno opredelili aktivnosti za dosego cilja z določenim postopkom zbiranja podatkov. Primer akcijskega načrta podajamo v nadaljevanju $\mathrm{v}$ Tabelah 42 in 43.

Tabela 42: Časovni in vsebinski potek akcijskega raziskovanja

\section{ČAS}

SEPTEMBER / 2017

AKCIJSKI KORAK 1

- OBLIKOVANJE STROKOVNIH TIMOV

- akcija: teoretična izhodišča za timsko delo

- akcija: načrtovanje in priprava dejavnosti za uvajanje elementov timskega dela

\section{AKTIVNOSTI ZA SISTEMATIČNO} RAZVIJANJE TIMSKEGA DELA

- oblikovanje akcijskega načrta za samoevalvacijo

- UVAJANJE SPREMEMBE: OBLIKOVANJE STROKOVNIH TIMOV

- Analiza osebne pripravljenosti delovanja v timu

- dogovor o stalnem terminu srečanj timov (mesečna srečanja)

- oblikovanje pravil, razdelitev vlog, dogovor o metodah dela

FEBRUAR / 2018

AKCIJSKI KORAK 2

- merjenje učinkovitosti tima

- akcija: timska evalvacija in refleksija

- akcija: ugotavljanje razvojne faze tima

- izobraževanje (4 ure): Timsko delo (dr. Alenka Polak)

- obravnava in sprejem akcijskega načrta tima za šolsko leto 2017/18

- pregled in evalvacija aktivnosti za preteklo obdobje

- UVAJANJE SPREMEMBE: SPROTNO MERJENJE ZAZNAVANJA UČINKOVITOSTI VODSTVENEGA TIMA (VPRAŠALNIK)

MAJ/ 2018

AKCIJSKI KORAK 3

- akcija: polletna evalvacija tima; individualna refleksija z diskusijo; izhodišča za AKCIJSKI KORAK (4)

\section{AKCIJSKI KORAK 4}

- načrtovanje in priprava dejavnosti za uvajanje elementov timskega dela

- akcija: oblikovanje vizije timskega dela za naslednje šolsko leto

- skupna predstavitev delovanja timov (razvojno in vsebinsko)
- vodstveni tim razpravlja o finančnih, organizacijskih in pravnih vprašanjih na ravni vrtca

- UVAJANJE SPREMEMBE: POLLETNA EVALVACIJA DELOVANJA TIMA (VPRAŠALNIK Z DISKUSIJO)

- ANALIZA POLLETNE EVALVACIJE 
ČAS

\begin{tabular}{ll}
\multicolumn{1}{c}{ ČAS } & \multicolumn{1}{c}{ AKTIVNOSTI ZA SISTEMATIČNO } \\
RAZVIJANJE TIMSKEGA DELA
\end{tabular}

Tabela 43: Čas zbiranja podatkov s posameznimi raziskovalnimi pripomočki

\begin{tabular}{ll}
\multicolumn{1}{c}{ ČAS } & \multicolumn{1}{c}{ POSTOPEK ZBIRANJA PODATKOV } \\
OKTOBER 2017 & $\begin{array}{l}\text { Vprašalnik za analizo osebne pripravljenosti za sodelovanje v timu Vprašalnik } \\
\text { za analizo osebne pripravljenosti za sodelovanje v timu (Polak, 1999 in 2001) }\end{array}$ \\
\hline \multirow{2}{*}{ FEBRUAR 2018 } & $\begin{array}{l}\text { merjenje zaznavanja učinkovitosti timov - Vprašalnik za sprotno merjenje za- } \\
\text { znavanja učinkovitosti tima (oblikovala S. Komočar po Arcaro, 1995: 14-15) } \\
\text { TIMSKA REFLEKSIJA }\end{array}$ \\
\hline \multirow{2}{*}{ MAJ 2018 } & $\begin{array}{l}\text { polletna evalvacija Vprašalnik za oceno delovanja tima (izvirnik Maas in } \\
\text { Ritschl, 1997,prevedla in delno priredila A. Kobolt v Kobolt, 2010: 184-186) }\end{array}$ \\
OKTOBER 2018 & $\begin{array}{l}\text { končna evalvacija delovanja timov - Vprašalnik za končno evalvacijo timskega } \\
\text { dela in nov začetek (prirejen po vprašalniku Intervizija in supervizija-evalva- } \\
\text { cija; (c) Simona Tancig, PeF, 2011) in diskusija }\end{array}$ \\
Analiza evalvacije timov (povratna informacija vodstva, dodatna refleksija ti- \\
mov, nadaljevanje razvoja tima z oblikovanjem novih ciljev, morebitnih no- \\
vih pravil, vizije) \\
Anketni vprašalnik \\
SAMOEVALVACIJA - evalvacija doseganja zastavljenega cilja za šolsko leto \\
2018/19
\end{tabular}

$\mathrm{Z}$ upoštevanjem elementov akcijskega raziskovanja smo člani vodstvenega tima uvajali spremembe (elemente timskega dela) $v$ strokovne time in jih skupaj z njimi sprotno in končno evalvirali. Glede na to, da temelji proces spodbujanja in razvijanja timskega dela na vzporednem spodbujanju refleksivnosti članov tima, smo želeli s sistematičnim uvajanjem sprememb $\mathrm{v}$ vodstveni tim vrtca razvijati tudi odgovornost članov posameznega strokovnega tima za aktivno lastno vlogo pri spodbujanju razvoja tima. Razvoj timskega dela smo prepletli skozi več ravni delovanja vrtca (strokovni ak- 
tivi, pedagoške konference, operativni sestanki, samoevalvacija, hospitacije) in tako razvijali aktivno, učečo se skupnost. Prednostna naloga vrtca je bila hkrati tudi izbrano področje ugotavljanja in zagotavljanja kakovosti vrtca, prednostno področje kakovosti pa je bil profesionalni razvoj, kar je razvidno iz primera samoevalvacijskega načrta v Tabeli $44 \mathrm{v}$ nadaljevanju.

Tabela 44: Dejavnosti in merila v šolskem letu 2017/18

\begin{tabular}{|c|c|c|c|c|}
\hline DEJAVNOSTI & $\begin{array}{c}\text { NOSILEC } \\
\text { DEJAVNOSTI }\end{array}$ & $\begin{array}{l}\text { VKLJUČENI V } \\
\text { DEJAVNOST }\end{array}$ & $\begin{array}{c}\text { ROK ZA } \\
\text { IZVEDBO } \\
\text { DEJAVNOSTI }\end{array}$ & $\begin{array}{l}\text { POTREBNI } \\
\text { VIRI }\end{array}$ \\
\hline Predavanje Timsko delo & $\begin{array}{l}\text { Silvija Komočar, } \\
\text { mag.prof.pred.vzg. } \\
\text { dr. Alenka Polak }\end{array}$ & & $\begin{array}{l}\text { oktober } 2017 \\
\text { februar } 2018\end{array}$ & \multirow[b]{10}{*}{$\begin{array}{l}\text { TIMA } \\
\text { kih in razvo- } \\
\text { m področju } \\
\text { delovanju, }\end{array}$} \\
\hline $\begin{array}{l}\text { Strokovne razprave na } \\
\text { aktivih }\end{array}$ & vodje aktivov & $\begin{array}{l}\text { strokovne de- } \\
\text { lavke }\end{array}$ & $\begin{array}{l}\text { oktober } 2017 \\
\text { januar } 2018 \\
\text { maj } 2018\end{array}$ & \\
\hline $\begin{array}{l}\text { Strokovni pogovori v } \\
\text { timu }\end{array}$ & strokovni delavci & $\begin{array}{l}\text { strokovni de- } \\
\text { lavci }\end{array}$ & $\begin{array}{l}\text { september } \\
\text { 2017-avgust } 2018\end{array}$ & \\
\hline $\begin{array}{l}\text { Načrtovanje timske- } \\
\text { ga dela }\end{array}$ & strokovni delavci & $\begin{array}{l}\text { strokovni de- } \\
\text { lavci }\end{array}$ & do maja 12018 & \\
\hline $\begin{array}{l}\text { Evalviranje timske- } \\
\text { ga dela }\end{array}$ & strokovni delavci & $\begin{array}{l}\text { strokovni de- } \\
\text { lavci }\end{array}$ & do maja 2018 & \\
\hline $\begin{array}{l}\text { Naloge znotraj tima v } \\
\text { povezavi s kurikularnim } \\
\text { področjem Gibanja }\end{array}$ & strokovni delavci & $\begin{array}{l}\text { strokovni de- } \\
\text { lavci }\end{array}$ & do maja 2018 & \\
\hline $\begin{array}{l}\text { Evalviranje nalog znot- } \\
\text { raj tima(kurikularno po- } \\
\text { dročje gibanja) }\end{array}$ & strokovni delavci & $\begin{array}{l}\text { strokovni de- } \\
\text { lavci }\end{array}$ & do maja 2018 & \\
\hline $\begin{array}{l}\text { Oblikovati pogoje za } \\
\text { timsko delo }\end{array}$ & $\begin{array}{l}\text { ravnateljica } \\
\text { pomočnica ravna- } \\
\text { teljice }\end{array}$ & $\begin{array}{l}\text { strokovni de- } \\
\text { lavci }\end{array}$ & do maja 2018 & \\
\hline $\begin{array}{l}\text { Študij strokovne litera- } \\
\text { ture o timskem delu in o } \\
\text { področju gibanja }\end{array}$ & strokovni delavci & $\begin{array}{l}\text { strokovni de- } \\
\text { lavci }\end{array}$ & ves čas & \\
\hline $\begin{array}{l}\text { MERILA } \\
\text { PODATKI }\end{array}$ & \multicolumn{3}{|c|}{$\begin{array}{l}\text { MERILO: UČINKOVITOST, RAZVOJ IN DELOVANJE TIMA } \\
\text { Načini pridobivanja podatkov: } \\
\text { Anketni vprašalniki: } \\
\text { Merjenje učinkovitosti tima } \\
\text { Merjenje razvoja tima } \\
\text { Merjenje delovanja tima } \\
\text { Opazovanje in beleženje lastne refleksije o timskih sestankih in razvo- } \\
\text { ju tima, timskem delu } \\
\text { Beleženje sprememb, ki so nastale v delovanju tima } \\
\text { Evalvacije in refleksije načrtovanja in dela na kulikularnem področju } \\
\text { Gibanje } \\
\text { Analiza strokovnih razprav na aktivih } \\
\text { Dnevniki zapisov (o izvedenih dejavnostih, o timskem sodelovanju, } \\
\text { nastalih težavah, uspešnih rešitvah, dilemah,...) }\end{array}$} & \\
\hline
\end{tabular}




\section{Rezultati in interpretacija}

Načrtovani cilj smo na nivoju vrtca v veliki meri dosegli. Na doseganje cilja je vplivalo:

- načrtovane dejavnosti,

- pripravljenost na timsko delo,

- menjavanje članov v timu.

V raziskovalni proces je bilo v šolskih letih 2017/18 in 2018/19 pri doseganju prioritetnega cilja vključenih od 53 do 60 strokovnih delavcev. Število strokovnih delavcev je naraščalo zaradi odprtja novih medletnih oddelkov. Do menjave strokovnih delavcev $\mathrm{v}$ timu je prihajalo tudi zaradi dolgotrajnih bolniških odsotnosti. Z vstopom novih članov je v timih prišlo do sprememb dinamike delovanja timov.

$\mathrm{Na}$ prvem strokovnem aktivu oktobra 2017 smo timom na kratko predstavili timsko delo, naloge, povezane s kurikularnim področjem gibanja ter metode in oblike dela, ki jih lahko uporabijo pri delu v timih. Timi so na prvem timskem sestanku:

- izbrali vodjo tima,

- predstavili drug drugemu svoja pričakovanja, želena pravila in načine dela,

- določili pravila v timu.

Tabela 45: Primerjava rezultatov zaznavanja elementov timskega dela

\section{Elementi timskega dela}

ŠOLSKO LETO 2017/18 ŠOLSKO LETO 2018/19

\begin{tabular}{lcc} 
SKUPNI CILJ & $98,1 \%$ & $100 \%$ \\
\hline SKUPNA NALOGA & $98,1 \%$ & $100 \%$ \\
\hline ČAS, NAMENJEN TIMSKIM SESTANKOM & $79,2 \%$ & $96,6 \%$ \\
\hline PROSTORSKI POGOJI & $83 \%$ & $89,5 \%$ \\
\hline
\end{tabular}

Vodstveni tim je za time pripravil anketni vprašalnik za sprotno merjenje učinkovitosti tima. Rezultati ankete so pokazali prisotnost elementov timskega dela $v$ posameznem timu in s tem so timi lahko pridobili informacijo o tem, katere spremembe je potrebno vnašati v posamezni tim, da bi se iz skupine razvil visoko funkcionalen tim. Člani timov v 92,6 \% ocenjujejo, da so kot tim dobro opravili zastavljeno nalogo s področja gibanja. 7, $4 \%$ članov je mnenja, da naloge kot tim niso dobro opravili. Iz poročil je razvidno, da člani vidijo tudi možnosti za izboljšavo zastavljene naloge. 
Rezultati in primerjave so pokazale, da so strokovni delavci dosegli zastavljen cilj. Iz primerjav je razvidno, da so se izboljšali rezultati glede organizacije časa in prostora kot dveh pogojev za timsko delo. Prostor je še vedno ocenjen kot neprimeren pri določenih članih tima, ki pa so podali argument in razlago, da so sami izbrali prostor, ki ni najbolj primeren. Imeli so možnost zamenjati prostor, a so se sami odločili, da bodo delali naprej v istem prostoru.

\section{Tabela 46: Primerjava rezultatov osebne pripravljenosti za timsko delo}

\section{Osebna pripravljenost za timsko delo}

\begin{tabular}{ll} 
September 2017 & Maj 2019 \\
\hline $\begin{array}{l}\text { Timsko delo vidim kot odličen način svojega } \\
\text { strokovnega dela in sodelovanja }\end{array}$ & $\begin{array}{l}\text { Timsko delo vidim kot odličen način svojega } \\
\text { strokovnega dela in sodelovanja }\end{array}$ \\
\hline $20,8 \%$ & $68,4 \%$ \\
\hline
\end{tabular}

Člani v večji meri zaznajo timsko delo kot odličen način njihovega strokovnega dela in sodelovanja. Strokovni delavci so na strokovnih aktivih izrazili željo, da se timsko delo nadaljuje ter da se ohranijo obstoječi timi. Strokovni pogovori v timu so prispevali k razvijanju sposobnosti za timsko delo. Strokovne delavke navajajo, da so skozi strokovne pogovore v timu razvile predanost in naklonjenost timu, da so čutile večjo soodgovornost za izvajanje zastavljene naloge. Posamezni strokovni delavci menijo, da skupni cilj, združevanje različnih pogledov, vidikov in izkušenj, nadgrajevanje idej, spoznavanje različnih močnih in šibkih področij (lastnih in od drugih članic tima), načrtovanje, kako učinkoviteje opraviti delo, razvijajo sposobnost za timsko delo. Strokovni delavci so skozi timsko delo in strokovne pogovore spremenili in izboljšali svoj način sodelovanja. Strokovni delavci navajajo, da so v timu slišani in sprejeti, da je njihovo mnenje pomembno ter uveljavljeno. Skozi strokovne pogovore so se strokovni delavci učili sprejemati mnenje drugih in sprejemati dejstvo, da nimajo vedno prav. Strokovni delavci so mnenja, da strokovni pogovori v timu dajo velik prispevek $\mathrm{k}$ razvijanju sposobnosti za timsko delo. Timske sestanke naj bi članice tima načrtovale že v začetku septembra v okviru timskega akcijskega načrta. Nekateri so sledili dogovorjenim datumom, nekateri timi pa so datume timskih sestankov načrtovali sproti, po dogovoru. Posamezni strokovni delavci navajajo, da so pri sprotnih dogovorih glede datuma sestanka imeli težave pri določitvi datuma. Strokovni delavci navajajo, da so si dela in naloge v timih razdelili glede na svoja močna področja, glede na znanja 
in spretnosti ter glede na sposobnosti vsakega posameznega člana tima. Posamezne naloge so si člani znotraj tima razdelili po tandemih.

\section{Zaključek}

Skozi razvoj timskega dela smo želeli vzpostaviti takšno raven medsebojnega sodelovanja in zaupanja med člani timov, da bi strokovni delavci znotraj teh ustvarjalnih delovnih celic najprej prepoznali že doseženo stopnjo lastnega poznavanja stroke in prakse in pridobili uvid v lastne sposobnosti in zmožnosti. Pričujoči rezultati kažejo, da so strokovni delavci raziskovanega vrtca $v$ svojih strokovnih timih pridobili pomembno medkolegijalno podporo in varno delovno in učno okolje, znotraj katerega z lastno aktivnostjo vplivajo na svoj profesionalni razvoj. Razvoj strokovnih timov je potekala po fazah razvoja, ki so izpostavljene v strokovni literaturi. Rezultati končne evalvacija delovanja timov, samoevalvacije in strokovne diskusije, ki je sledila refleksijam na srečanjih strokovnih aktivov, kažejo na to, da so timi razvili lastnosti, ki so značilne za učinkovite time. Člani se zavedajo pomembnosti lastne aktivnosti in odgovornosti posameznika za boljše delovanje tima in za lasten profesionalni razvoj. Člani strokovnih timov so bili skozi raziskovalni proces sodelovalno naravnani, spodbujali so drug drugega, odkrito so izražali svoja mnenja Zelo opazno je bilo kontinuirano naraščanje občutka pripadnosti posameznih članov svojemu timu. Člani timov so poudarili lastno motiviranost in željo po sodelovanju v enaki sestavi še naprej.

Glede na rezultate pričujoče raziskave lahko sklepamo, da je v vzgojno izobraževalnih organizacijah smiselno sistematično razvijati timsko delo, saj spodbudno vpliva tako na profesionalni razvoj zaposlenih kot na izboljšanje splošne organizacijske klime.

\section{Literatura}

Arcaro, Jerry. Teams in Education: Creating An Integrated Approach. Delray Beach, Florida: St. Lucie Press, 1995.

Berliner, David Charles. The Nature of Expertise in Teaching. V Oser, Fritz et. al. (ur.), Effective and Responsible Teaching: The New Synthesis (str. 227-249). San Francisco: Jossey Bass Publishers, 1992.

Bowers, C. A., Braun, C. C., \& Morgan, B. B. Team Workload: Its Meaning and Measurement. In M. T. Brannick, E. Salas, \& C. Prince (Eds.), Team 
Performance Assessment and Measurement (pp. 85-108). Mahwah, NJ: Lawrence Erlbaum, 1997.

Brajša, Pavao Sedem skrivnosti uspešne šole. Maribor: Doba, 1995.

Fuller, Frances F. Concerns of Teachers: A Developmental Conceptualization. American Educational Research Journal, 6(2), 207-226, 1969.

Kagan, Dona M. Professional Growth Among Preservice and Beginning Teacher. American Educational Research Journal, 2, 129-169, 1992.

Gladstein, Deborah L. Groups in Context: A Model of Task Group Effectiveness. Administrative Science Quarterly, 29(4), 499-517, 1984.

Guchait, Priyanko, Puiwa Lei and Michael J. Tews. Making Teamwork Work: Team Knowledge for Team Effectiveness. The Journal of Psychology, 150(3), 300-317, 2016.

Hwang, Mark I. Relationship between Teamwork and Team Performance: Experiences from an ERPsim Competition. Journal of Information Systems Education, 29(3), 157-168, 2018.

Javrh, Petra. Splošne in andragoške zakonitosti razvoja kariere. Ljubljana: Andragoški center Slovenije, 2011.

Kobolt, Alenka (ur.). Supervizija in koučing. Ljubljana: Pedagoška fakulteta. Zavod RS za šolstvo, 2010.

Kobolt, Alenka. Timsko delo - nuja in izziv. Vzgoja in izobraževanje, letnik XLIII, številka 3-4, 2012. Ljubljana: Zavod RS za šolstvo, 2012.

Kolb, David A. The challenges of advanced professional development. New York: Prentice-Hall, 1991.

Kozlowski, Steve W. J. and Katherine J. Klein. A Multilevel Approach to Theory and Research in Organizations: Contextual, Temporal, and Emergent Processes. In K. J. Klein \& S. W. J. Kozlowski (Eds.), Multilevel Theory, Research, and Methods in Organizations: Foundations, Extensions, and new directions, 2000.

Lepičnik-Vodopivec, Jurka. Priročnik Teorija in praksa sodelovanja s starši. Ljubljana: Pedagoška fakulteta, 2012.

LePine, Jeffery A., Ronald F. Piccolo, Christine L. Jackson, Mathieu, Jesica R. Saul. A Meta-Analysis of Teamwork Processes: Tests of a Multidimensional Model and Relationships with Team Effectiveness Criteria. Personnel Psychology, 61(2), 273-307, 2008.

Loughry, Misty L., Matthew W. Ohland and Moore, Dewayne Moore. Development of a Theory-Based Assessment of Team Member Effectiveness. Educational Psychological Measurement, 67, 505-524, 2007. 
Mayer, Janez. Nastajanje celostnega pogleda - ključ za ustvarjalnost tima. V Mayer, J. (in sod.). (2001). Skrivnost ustvarjalnega tima. Ljubljana: Dedalus - Center za razvoj vodilnih osebnosti in skupin, 2001.

Ohland, M. W., Loughry, M. L., Woehr, D. J., Finelli, C. J., Bullard, L. J., Felder, R. M., \& Schmucker, D. G. The Comprehensive Assessment of Team Member Effectiveness: Development of a Behaviorally Anchored Rating Scale for Self and Peer Evaluations. Academy of Management Learning and Education, 11, 609-630, 2012.

Polak, Alenka. (1999 in 2001). Aktivnosti za spodbujanje in razvijanje timskega dela. Priročnik za timsko delo v šoli. Tempus Respect. Pedagoška fakulteta Univerze v Ljubljani. (uporabljeno s privoljenjem avtorice)

Polak, Alenka. Timsko delo v vzgoji in izobraževanju. Ljubljana: Modrijan, 2007.

Polak, Alenka. Razvijanje in reflektiranje timskega dela v vrtcu: priročnik. Pedagoška fakulteta Univerze v Ljubljani, 2012.

Robbins, Harvey and Michael Finley. The new why teams don't work: What goes wrong and how to make it right. Berrett-Koehler Publishers, 2000.

Rutar, Dušan. (ur.). Kognitivna znanost v šoli za 21. stoletje. Kamnik: Cirius, 2017.

Salas, Eduardo, Nancy J. Cooke and Michael A. Rosen. On Teams, Teamwork, and Team Performance: Discoveries and Developments. Human Factors, 50(3), 540-547, 2008.

Sheckley, B. G. in Allen, G. J. Experiential Learning: A Key to Adult Development. V L. Lamdin (ur.), Roads to the Learning Society (str. 99-109). Chicago: The Council for Adult and Experiential Learning, 1991.

Šagud, Mirjana in Anka Jurčević Lozančić. Značenje kritičke refleksije i samorefleksije za istraživanje i unapređivanje pedagoške prakse. V M. Ljubetić in B. Mendeš, (ur.). Prema kulturi (samo)vrednovanja ustanove ranog i predškolskog odgoja - izazov za promjene. Split: Nomen Nostrum $\mathrm{Mu}-$ dnić, 2012.

Tancig, Simona. Vprašalnik: Intervizija in supervizija-evalvacija; (c) Simona Tancig, PeF, 2011.

\section{Viri}

Katz, Lilian. G. (1972). Developmental Stages of Preschool Teachers. The Elementary School Journal,73(1), 50-54. Pridobljeno s http://www.jstor.org/ stable/1000851 (8. 12. 2019) 
Gregurić, Mirjana, Ljubica Bakić-Tomić, and Ana Globočnik Žunac. „Primary School Teachers' Competence in Solving Interpersonal Conflicts.“ In The 3rd International Conference on Advances and Systems Research. 2009. https://www.bib.irb.hr/462618? $\mathrm{rad}=462618$ (8. 12. 2019)

Noonan, James. (2019). An Affinity for Learning: Teacher Identity and Powerful Professional Development. Journal of Teacher Education, 70(5), 526537. https://doi.org/10.1177/0022487118788838 (10. 12. 2019)

Valenčič Zuljan, Milena in Danijela Blanuša Trošelj. (2014). Profesionalni razvoj vzgojiteljev z vidika vzgojiteljevih pojmovanj. Andragoška Spoznanja, 2o(1), 43-6o. https://doi.org/10.4312/as.20.1.43-6o (8. 12. 2019) 